ACTA THERIOLOGICA

Vol. 33, 3: 35-46, 1988

\title{
Relationship of Skull Dimensions with Latitude in the Japanese Field Vole
}

\author{
Yukibumi KANEKO
}

\begin{abstract}
Kaneko Y. 1988: Relationship of skull dimensions with latitude in the Japanese field vole. Acta theriol., 33, 3: 35-46. [With 2 Tables \& 3 Figs.]

After examining seasonal variation by analysis of variance, 11 skull dimensions were correlated with latitude in 623 reproductively mature specimens of Microtus montebelli (Milne-Edwards, 1872) collected from 15 localities in Honshu and Kyushu and on Sado Island, Japan. In both sexes, a significant reverse correlation with latitude was found in condylobasal length (CBL) and certain dimensions of the braincase, face, and interorbital, but not in the lengths of the dentition and incisive foramen. These data and other references suggest that in Microtus most species and subspecies that do not conform to Bergmann's rule occur primarily at lower latitudes of the Northern Hemisphere, whereas most species and subspecies that do conform to the rule occur primarily at higher latitudes.
\end{abstract}

[Biological Laboratory, Faculty of Education, Kagawa University, Takamatsu 760, Japan]

\section{INTRODUCTION}

Voles of the genus Microtus occur in temperate and boreal zones of Europe, Asia, northern Africa, and North America. Latitudinal variation in size has been studied in several species of Microtus. The results of these studies are of three types relative to Bergmann's rule: two species obey the rule (Southern, 1964; Tast, 1966); five species do not (Hall, 1935; Dale, 1940; Stein, 1957; Anderson, 1959; Findley \& Jones, 1962; Choate \& Williams, 1978); one species obeys the rule in some instances but not in other instances (Dale, 1940; Goin, 1943; Snyder, 1954; McNab, 1971; Martell, 1975; Snell \& Cunnison, 1983).

The Japanese field vole, M. montebelli, is an endemic Japanese species that occurs in Honshu and Kyushu and on Sado Island. Latitudinal variation in this species previously has not been investigated.

This paper presents data on latitudinal variation in skull dimensions in $M$. montebelli and compares the patterns of variability found with those in several other species of Microtus.

\section{MATERIAL AND METHODS}

I examined 623 reproductively mature (adult) specimens of $M$. montebelli collected with snap-traps at 15 localities, 11 in Honshu, three in Kyushu, and one 


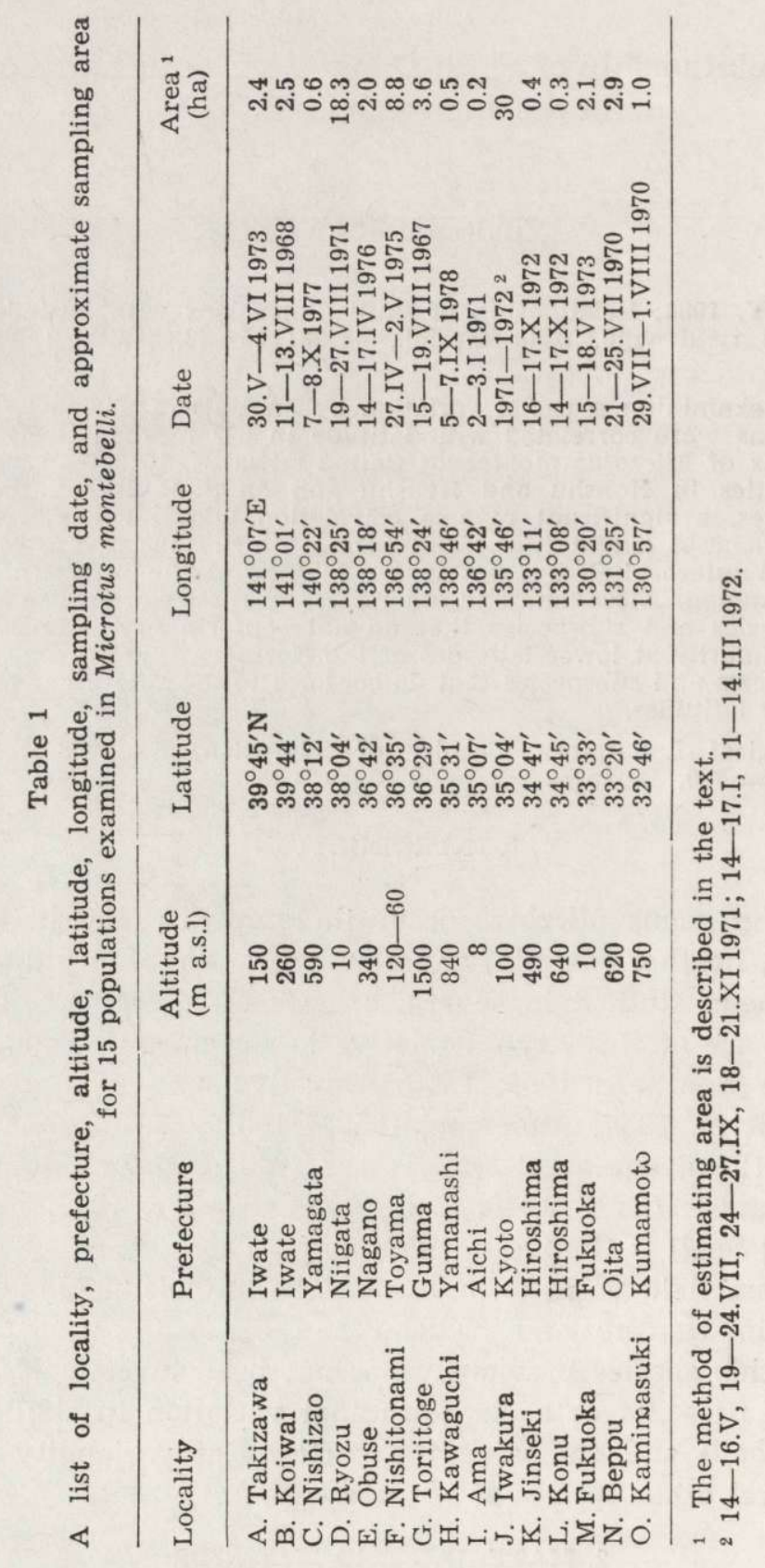


on Sado Island (Table 1). Specimens (109 males, 76 females) from the Iwakura population, Kyoto, were collected bi-monthly for a year in order to assess seasonal variation. Other populations were sampled just once. Latitude, longitude, and altitude of the collection sites were determined by topographic maps (scale 1:25000 prepared by the National Geographical Institute of Japan. The area of each collection site was estimated from a map.

The specimens collected were preserved in $10 \%$ formaldehyde solution in the field after external measurements were taken. Skulls were extracted and cleaned prior to taking cranial measurements.
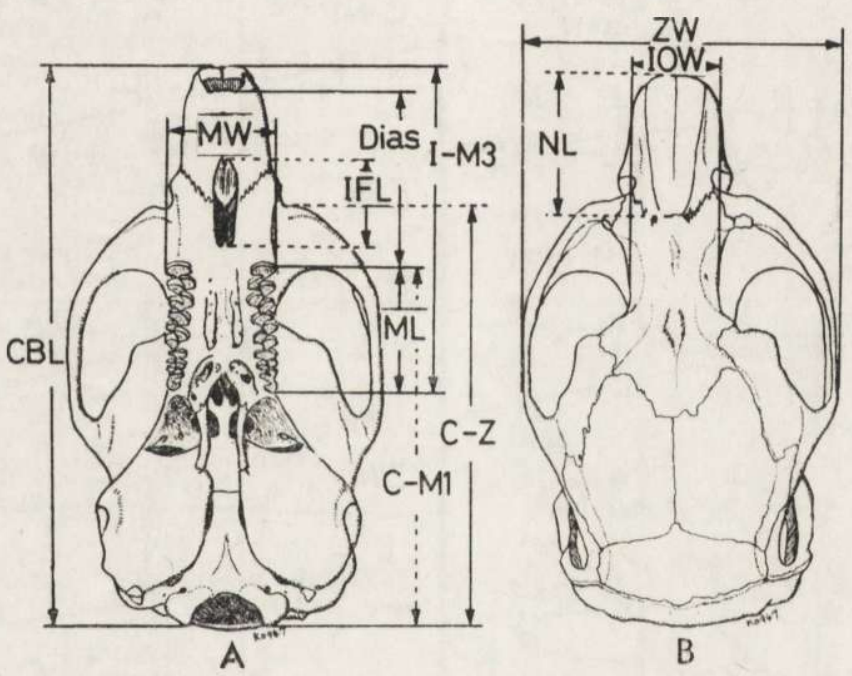

Fig. 1. Ventral (A) and dorsal (B) views of the skull of Microtus montebelli. Abbreviations of dimensions are explained in text.

Eleven skull dimensions (Fig. 1) were taken to the nearest $0.1 \mathrm{~mm}$ using a dial caliper; paired structures were measured on the left side: Condylobasal length (CBL)-distance between occipital condyle and anterior point of premaxillae; Condylo-zygomatic length $(\mathrm{C}-\mathrm{Z})$ - distance between occipital condyle and anteriorsuperior edge of premaxillae; Condylo-molar 1 length $\left(C-\mathrm{M}^{1}\right)$-distance between occipital condyle and anterior edge of $\mathrm{M}^{\mathbf{1}}$; Incisive-molar 3 length (I- $\left.\mathrm{M}^{3}\right)$-distance from the most anterior point on incisor to the most posterior edge of $\mathrm{M}^{3}$; Length of diastema (Dias)-distance from the posterior $\in$ dge of incisive alveolus to anterior edge of alveolar space of molar row; Molar length (ML)-distance from the most anterior edge of $\mathbf{M}^{1}$ to the most posterior edge of $\mathrm{M}^{3}$; Length of incisive foramen (IFL)-maximum length of palatine slit; Length of nasal (NL)-maximum length of nasal bone; Zygomatic width (ZW)-maximum spread of zygomatic arches; Interorbital width (IOW) - least diameter of frontal bones between orbits; Molar width (MW)-maximum distance between the lateral borders of $\mathrm{M}^{1}$.

Dimensions were compared in adults because Zejda (1971) pointed out that somatic growth is closely correlated with sexual maturity and may not be correlated with actual age. Females were considered to be mature when embryos in the uterus were visible or the pubic symphysis was open (Kaneko, 1968). Males 


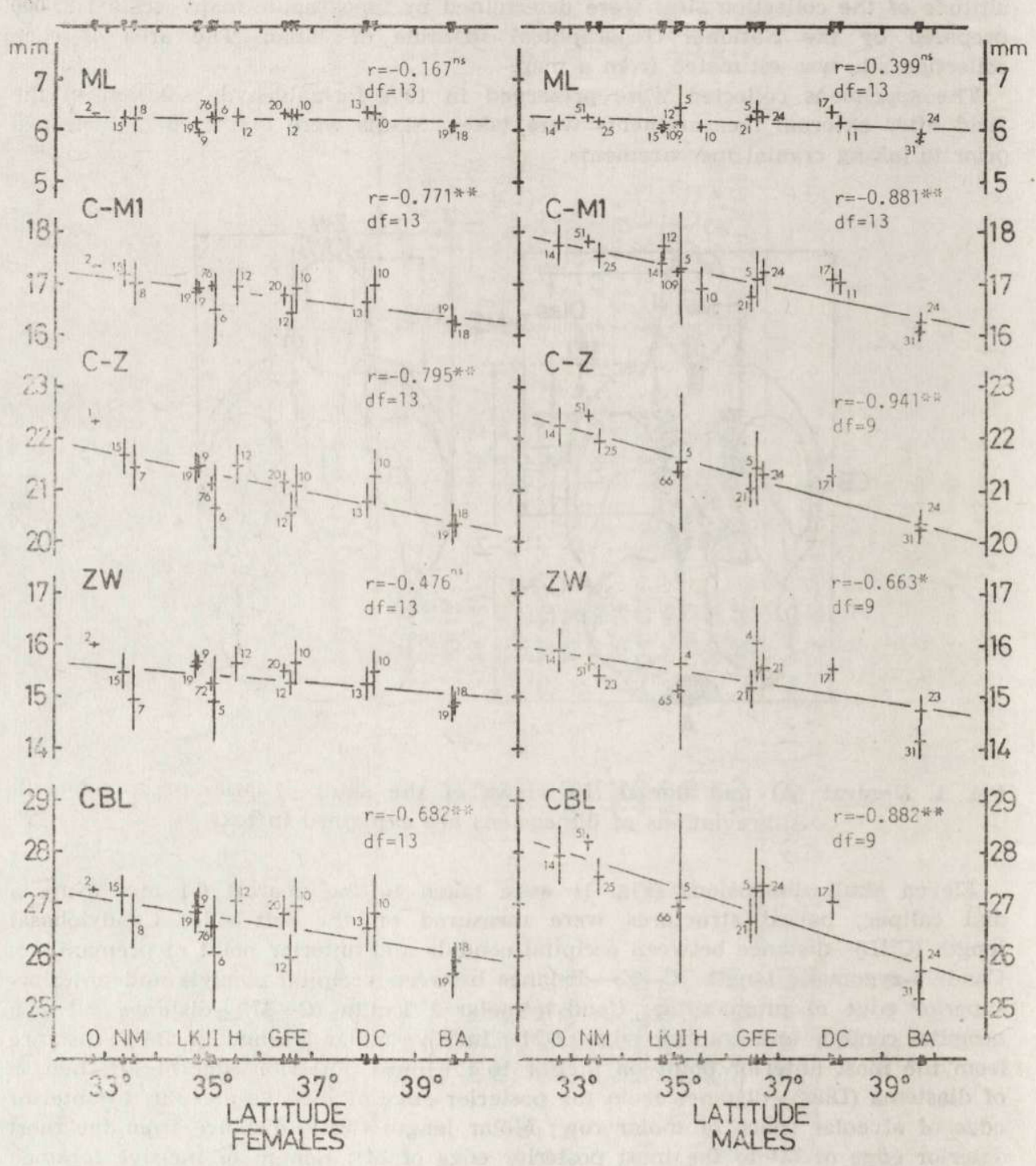

Fig. 3. Relationships between skull dimensions and degrees of latitude in Microtus montebelli. A solid vertical line represents a sample mean $\pm 95 \%$ confidence limits with the number of specimens examined at each locality $(\mathrm{A}-\mathrm{O})$. Localities corresponding to capital letters $(\mathrm{A}-\mathrm{O})$ are provided in Table 1. One asterisk $(0.01<p<0.05)$, two asterisks $(p<0.01)$, and ns (not significant). 


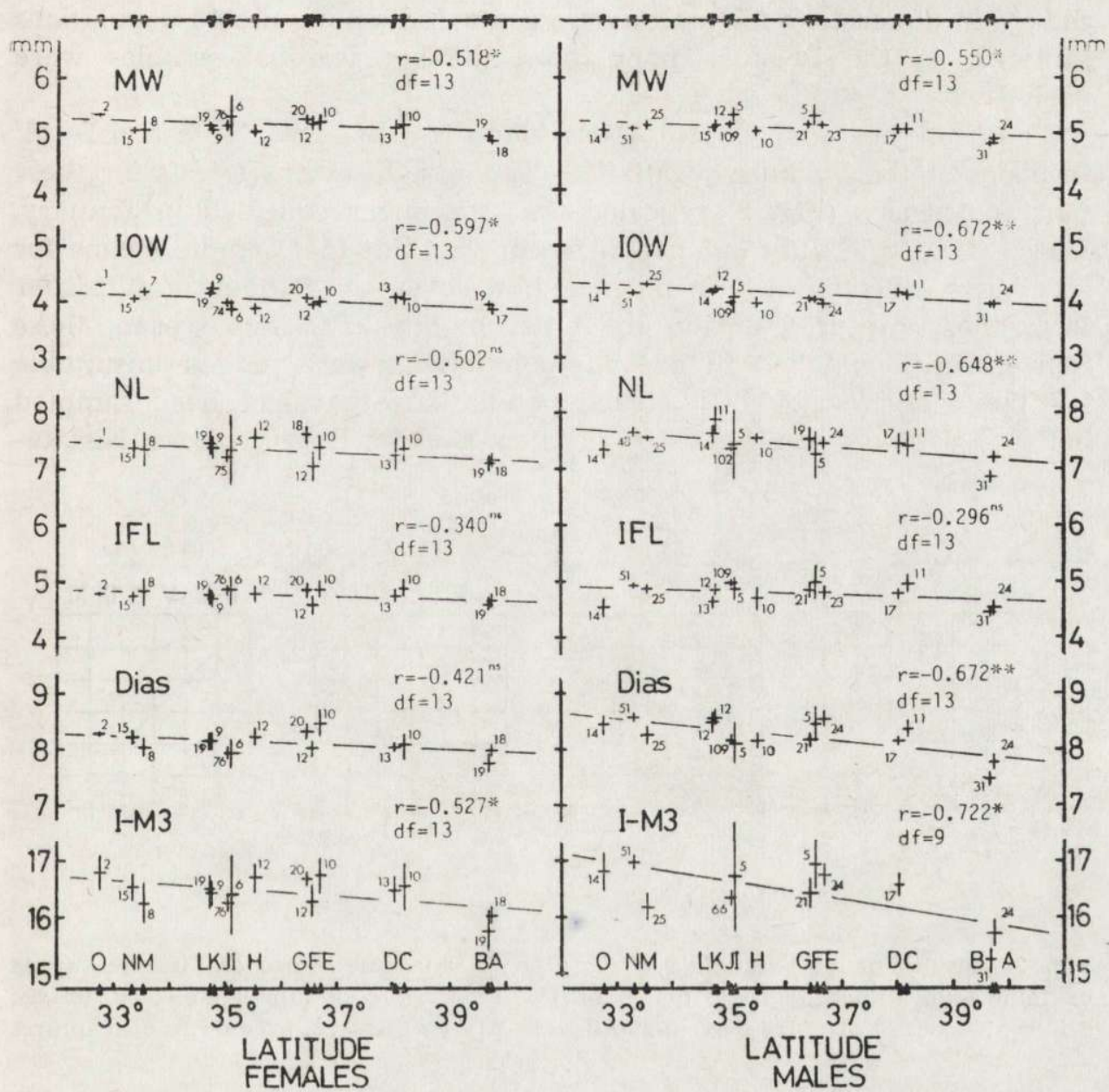

Fig. 3. concluded.

were regarded as mature when tubules of the cauda epididymis were clearly visible to the naked eye. In this condition, sperm was present in the tubules (Arai et al., 1983).

\section{RESULTS}

Coefficients of variation (CV) for the 11 skull dimensions ranged from 3.01 ( $\mathrm{I}-\mathrm{M}^{3}$ in males) to 6.59 (IFL in females) in adults of the Iwakura population (76 females and 109 males). Table 2 shows that no significant seasonal variation was detectable in any of the measurements in females, or in $\mathrm{C}_{-} \mathrm{M}^{1}, \mathrm{ML}$, Dias, IFL, NL, MW, and IOW in males in that population using analysis of variance. Therefore, all the dimensions for females and 
the seven dimensions for males were compared among the 15 populations sampled; in the Iwakura population, the six seasonal samples were pooled.

Significant seasonal variation was found in $\mathrm{CBL}, \mathrm{ZW}, \mathrm{C}-\mathrm{Z}$ and $\mathrm{I}-\mathrm{M}^{3}$ in males of the Iwakura population (Table 2). Student's $t$-tests for these four dimensions (Fig. 2) revealed that specimens collected in January, March, May, and July did not differ in size, but that sample means for specimens collected in September and/or November frequently did differ from those captured during the other months. For this reason, these four dimensions taken in autumn populations were judged unsuitable for the comparison. Thus, eleven populations that had been sampled between January and August (Takizawa, Koiwai, Ryozu, Obuse, Nishito-

CBL

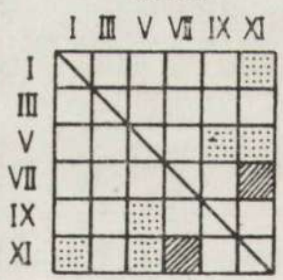

$p \gg 0.05$
ZW

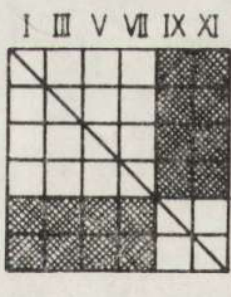

$0.02 \leqslant p<0.05$
$C-Z$

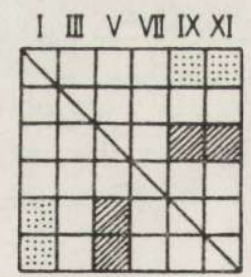

$0.01 \leqslant p<0.02$
$1-M 3$

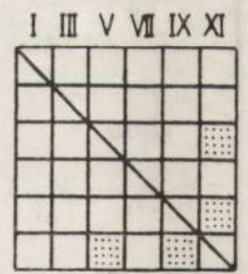

$p<0.01$

Fig. 2. Results of the Student's $t$-test used to analyze differences in the means of four skull dimensions for males of the Iwakura populations collected in six different months. The roman numerals (I-XI) correspond to month of capture.

nami, Toriitoge, Ama, Iwakura [January, March, May, and July], Fukuoka, Beppu, and Kamimasuki) (see Table 1) were selected for analysis of latitudinal variation of $\mathrm{CBL}, \mathrm{ZW}, \mathrm{C}-\mathrm{Z}$, and $\mathrm{I}-\mathrm{M}^{3}$ in males.

Fig. 3 illustrates a significant correlation with latitude for $\mathrm{CBL}, \mathrm{C}-\mathrm{Z}$, $\mathrm{C}-\mathrm{M}^{1}, \mathrm{I}-\mathrm{M}^{3}$, IOW, and $\mathrm{MW}$ of females and for $\mathrm{CBL}, \mathrm{ZW}, \mathrm{C}-\mathrm{Z}, \mathrm{C}-\mathrm{M}^{1}$, $\mathrm{I}-\mathrm{M}^{3}$, Dias, NL, IOW, and MW of males. No significant correlation was observed in ZW, ML, Dias, IFL, or NL of females, nor in ML or IFL of males. Thus, the number of dimensions selected for analysis of latitudinal variation was greater in males than in females. Furthermore, in both sexes, CBL, C-Z, C- $\mathrm{M}^{1}, \mathrm{I}-\mathrm{M}^{3}$, and interorbital parts (IOW and MW) were negatively correlated with latitude, whereas ML and IFL showed no relationship with latitude. In males, Dias and $\mathrm{ZW}$ also decreased as latitude increased. 
Table 2

Results of an analysis of variance for skull dimensions in the Iwakura population of Microtus montebelli sampled during six different months through the year.

\begin{tabular}{|c|c|c|c|}
\hline \multirow{2}{*}{ Dimensions } & Females & \multicolumn{2}{|c|}{ Males } \\
\hline & \multicolumn{3}{|c|}{$F$-ratio (df) } \\
\hline CBL & $1.215(5 / 70)$ & $2.818^{*}$ & $(5 / 103)$ \\
\hline $\mathrm{ZW}$ & $0.532(5 / 66)$ & $5.055^{* *}$ & $(5 / 101)$ \\
\hline $\mathrm{C}-\mathrm{Z}$ & $1.479(5 / 70)$ & $2.680^{*}$ & (5/103) \\
\hline $\mathrm{C}-\mathrm{M}^{1}$ & $0.910(5 / 70)$ & 2.011 & $(5 / 103)$ \\
\hline ML & $0.537(5 / 70)$ & 1.986 & (5/103) \\
\hline $\mathrm{I}-\mathrm{M}^{3}$ & $1.320(5 / 70)$ & $2.431^{*}$ & (5/103) \\
\hline Dias & $2.274(5 / 70)$ & 2.275 & (5/103) \\
\hline IFL & $1.844(5 / 70)$ & 0.290 & $(5 / 103)$ \\
\hline NL & $0.991(5 / 69)$ & 1.362 & $(5 / 96)$ \\
\hline MW & $0.808(5 / 70)$ & 1.368 & $(5 / 103)$ \\
\hline IOW & $1.135(5 / 68)$ & 0.378 & $(5 / 103)$ \\
\hline
\end{tabular}

\section{DISCUSSION}

A positive correlation in body weight with latitude in homoiotherms has been known as Bergmann's rule (McNab, 1971). Although body weight (BW) and head and body length (HBL) are standard measurements of size in mammals, BW and HBL vary with seasons in $M$. montebelli (Kaneko, 1978) and analysis of variance shows a significant seasonal difference in BW and HBL in the adults of the Iwakura population sampled during six different months through a year: $F=11.273(d f=5 / 103)$ in male BW; $F=2.530(d f=5 / 70)$ in female BW; $F=15.819(d f=5 / 103)$ in male HBL; $F=2.909(d f=5 / 70)$ in female HBL. Therefore, CBL is used as a standard measurement of body size in this vole in the following discussion, because CBL correlates significantly with BW and HBL in the adults of the Iwakura population: $r=0.595(d f=107)$ in male BW; $r=0.490(d f=74)$ in female BW; $r=0.519(d f=107)$ in male HBL; $r=0.535$ $(d f=74)$ in female HBL.

Latitudinal variation of body size and/or skull size in Microtus does not always comply with Bergmann's rule. Literature on the subject reveals three patterns: $M$. oeconomus (Tast, 1966) and $M$. agrestis (Southern, 1964; Tast, 1966) obey the rule; M. arvalis (Stein, 1957), M. montanus (Hall, 1935; Anderson, 1959; Findley \& Jones, 1962), M. californicus (Dale, 1940), M. longicaudus (Dale, 1940; Findley \& Jones, 1962), and $M$. ochrogaster (Choate \& Williams, 1978) contradict the rule; and M. pennsylvanicus obeys the rule in some instances (McNab, 1971; Martell, 1975) but not in others (Dale, 1940; Goin, 1943; Snyder, 1954; McNab, 1971; Snell \& Cunnison, 1983). In M. montebelli, a reverse cor- 
relation with latitude was observed in CBL of both sexes (Fig. 3). Therefore, M. montebelli seems to conform to the second pattern as far as the relationship of latitudinal variation to Bergmann's rule is concerned.

The three patterns mentioned above can be explained in terms of the distributions of the species (Zimmermann, 1942; van den Brink, 1967; Hall, 1981) with one exception (M. longicaudus). The two species whose size obeys the rule are distributed at high latitudes in the Northern Hemisphere $\left(M\right.$. oeconomus and $M$. agrestis, $\left.50^{\circ}-70^{\circ} \mathrm{N}\right)$. The five species whose sizes do not obey the rule are distributed at low latitudes ( $M$. montebelli, $31^{\circ}-41.5^{\circ} \mathrm{N} ; M$. arvalis, $40^{\circ}-60^{\circ} \mathrm{N} ; M$. montanus, $34^{\circ}-50^{\circ} \mathrm{N}$; M. californicus, $31^{\circ}-43^{\circ} \mathrm{N} ; M$. ochrogaster, $\left.30^{\circ}-53^{\circ} \mathrm{N}\right)$. The species that obeys the rule in some instances but not in others, $M$. pennsylvanicus, ranges from $33^{\circ} \mathrm{N}$ to $70^{\circ} \mathrm{N}$. Its body and skull sizes increase toward the north at latitudes greater than $55^{\circ} \mathrm{N}$ (McNab, 1971; Martell, 1975), but increase toward the south at latitudes less than $55^{\circ} \mathrm{N}$ (Dale, 1940; Goin, 1943; Snyder, 1954; McNab, 1971). The same pattern in M. pennsylvanicus can be seen in the figure by Snell \& Cunnison (1983), though they mentioned only that the largest voles occur in the south and east and smaller voles in the north and west.

M. longicaudus occurs over as broad a latitudinal range $\left(32^{\circ}-70^{\circ} \mathrm{N}\right)$ as does $M$. pennsylvanicus. Without presenting evidence, Dale (1940) stated that the size of this vole increased toward the south; Findley \& Jones (1962) showed an increase in size toward the south in New Mexico (around $34^{\circ} \mathrm{N}$ ). Bailey $(1900)$ demonstrated that subspecies at the northern part of the range obey the rule. Thus, M. longicaudus follows the same pattern as $M$. pennsylvanicus.

These findings suggest that species and subspecies of Microtus at lower latitudes of the Northern Hemisphere increase in size toward the south. Alternatively, species and subspecies of Microtus at higher latitudes increase in size toward the north.

The usual explanation of Bergmann's rule is that large animals have a thermoregulatory advantage in cold climates because of their small surface-volume ratio. Hesse et al. (1951) and Mayr (1963) suggested that burrowing animals, such as Microtus, Thomomys, and Talpa, may be exceptions to the rule because they are well protected against cold, particularly in areas with snow cover. Mayr (1963) further noted that, for burrowers, the amount of food available in the winter season is the decisive factor in determining body size. However, as mentioned above, some species and subspecies of Microtus exhibit the three patterns of body size gradients with latitude even though these taxa have similar habits for burrowing. Therefore, the explanations of Hesse et al. (1951) and Mayr (1963) are not fully satisfactory. 
McNab (1971) studied the relationship between body size and latitude of 47 eastern North American species divided into four latitudinal ranges. He showed that negative correlations of size with latitude were common at lower latitudes whereas positive correlations were usual at higher latitudes. Thus, the three patterns of body size gradients found in the present study correspond well to his findings. McNab (1971) further revealed that latitudinal changes in size were due either to the distribution of closely-related species of carnivores and granivores or to the distribution of their prey species and he regarded this relationship as an example of character displacement. From his findings, he expected that, because the largest species of voles occur in the north, the smallest species would not conform to Bergmann's rule and would become largest in the south. However, he failed to find the smallest voles increasing towards the south and could not understand the factors determining body size of grazers such as meadow voles. Although the distributions of $M$. longicaudus and $M$. montanus and of $M$. pennsylvanicus and $M$. ochrogaster are partly sympatric in the Rocky Mountains of North America (Hall, 1981), the body size of $M$. longicaudus, M. montanus, $M$. ochrogaster, and $M$. pennsylvanicus increases toward the south at low latitudes as mentioned above. Therefore, character displacement cannot fully explain latitudinal size relationships in Microtus.

Kalela (1957) found that body size correlates with litter size in $M$. oeconomus and $M$. agrestis and the litter size is larger in cooler climates, and thought that larger voles were selected by producing larger litter size in cooler climates. Hoyte (1955), Tast (1966), and Gustafsson et al. (1983) affirmed that litter size was larger in northern than in southern populations of $M$. oeconomus and $M$. agrestis. However, Innes (1978) demonstrated that litter size did not increase with latitude in $M$. californicus, $M$. montanus, $M$. ochrogaster, and $M$. pennsylvanicus; the litter size of $M$. pennsylvanicus was examined in the range from $38^{\circ} \mathrm{N}$ to $59^{\circ} \mathrm{N}$. The litter size of $M$. montebelli does not increase with increasing latitude in five local populations $(r=-0.512, d f=4, p>0.1)$ (Miyao et al., 1966; Shiraishi, 1967; Abe, 1974; Kaneko, 1976; Saito et al., 1980; Kimura et al., 1980). In $M$. arvalis, Reichstein (1964) found no clear geographic trends in litter size across northern and central Europe. As mentioned above, body size of $M$. oeconomus and $M$. agrestis living at high latitudes follows Bergmann's rule whereas the four species studied by Innes (1978), in addition to $M$. montebelli and $M$. arvalis, all of which occur at low latitudes show the reverse of Bergmann's rule. Therefore, Kalela's (1957) argument can only be adopted for the species of Microtus obeying Bergmann's rule and living at high latitudes.

Snell \& Cunnison (1983) discussed the reverse of Bergmann's rule in 
M. pennsylvanicus. They predicted that during times of extremely low temperatures smaller voles would be less energetically stressed than larger voles and larger size would be actively selected against. As stated before, the body size trend of $M$. pennsylvanicus differs between lower and higher latitudes (Dale, 1940; Goin, 1943; Snyder, 1954; McNab, 1971; Martell, 1975; Snell \& Cunnison, 1983). Because the number of their sample localities was greater at latitudes less than $55^{\circ} \mathrm{N}$ than at latitudes greater than $55^{\circ} \mathrm{N}$, their data may have been biased in favor of a statistically negative correlation over the entire geographical range of the vole. If so, their predictions would apply only to voles living at low latitudes. Thus, I suggest that any adaptive significance associated with increased size in some Microtus species may differ at lower and at higher latitudes.

Acknowledgements: I would like to thank J. R. Choate for critically reading and editing the manuscript, and M. Morishita, O. Murakami, T. Sunaga, T. Uematsu, M. Tasumi, K. Wada, N. C. Watanabe, K. Maeda, E. W. Jameson, Jr. and S. Anderson for making numerous and valuable suggestions on early drafts. I also thank many people who helped in the field. This paper was taken from parts of my doctoral thesis at Kyoto University, 1974.

\section{REFERENCES}

1. Abe T., 1974: An analysis of age structure and reproductive activity of $M i$ crotus montebelli population based on yearly trapping data. Jap. J. app. Ent. Zool., 18: 21-27. [In Japanese with English abstract]

2. Anderson S., 1959: Distribution, variation and relationships of the montane vole, Microtus montanus. Univ. Kansas Publ., Mus. Nat. Hist.. 9: 415-511.

3. Arai S., Shiraishi S. \& Uchida T. A., 1983: Population ecology of the Japanese field vole (Microtus montebelli) in Kyushu. VI. Criteria for determining breeding condition and breeding season. J. Fac. Agr., Kyushu Univ., 27: 165-178.

4. Bailey V., 1900: Revision of American voles of the genus Microtus. North Amer. Fauna, (17): 1-88.

5. van den Brink F. H., 1967: A field guide to the mammals of Britain and Europe. Collins: $1-221$, London.

6. Choate J. R. \& Williams S. L. 1978: Biogeographic interpretation of variation within and among populations of the prairie vole, Microtus ochrogaster. Occas. Pap. Mus. Texas Tech Univ., 58: 1-25.

7. Dale F. H., 1940: Geographic variation in the meadow mouse in British Columbia and southeastern Alaska. J. Mammal., 21: 332-340.

8. Findley J. S. \& Jones C. J., 1962: Distribution and variation of voles of the genus Microtus in New Mexico and adjacent areas. J. Mammal., 43: 154-166.

9. Goin O. B., 1943: A study of individual variation in Microtus pensylvanicus pennsylvanicus. J. Mammal., 24: 212-223.

10. Gustafsson T. O., Andersson C. B. \& Westlin L. M., 1983: Reproduction in laboratory colonies of bank vole, Clethrionomys glareolus, originating from populations with different degrees of cyclicity. Oikos, 40: 182-188. 
11. Hall E. R., 1935: Nevadan races of the Microtus montanus group of meadow mice. Univ. California Publ. Zool., 40: 417-427.

12. Hall E. R., 1981: The mammals of North America. Vol. 2. 2nd ed., John Wiley \& Sons: $601-1175$, New York.

13. Hesse R. C., Allee W. C. \& Schmidt K. P., 1951: Ecological animal geography. 2nd ed., Wiley: $1-715$, New York.

14. Hoyte H. M. D., 1955: Observations on reproduction in some small mammals of arctic Norway. J. Anim. Ecol., 24: 412-425.

15. Innes D. G. L., 1978: A reexamination of litter size in some North American microtines. Can. J. Zool., 56: 1488-1496.

16. Kalela O., 1957: Regulation of reproduction rate in subarctic populations of the vole Clethrionomys rufocanus (Sund.). Ann. Acad. Sci. Fenni., Ser. A., 9: $1-60$.

17. Kaneko Y., 1968: The comparative morphology of the pelvis and hind limb of Japanese Muroidea. I. The morphological changes of the pelvis and hind limb with the growth of Japanese meadow vole. Zool. Mag., 77: 367-373. [In Japanese with English abstract].

18. Kaneko Y., 1976: Reproduction of Japanese field voles, Microtus montebelli (Milne-Edwards) at Iwakura, Kyoto, Japan. Jap. J. Ecol., 26: 107-114.

19. Kaneko Y., 1978: Seasonal and sexual differences in absolute and relative growth in Microtus montebelli. Acta theriol., 23: 75-98.

20. Kimura Y., Saito T. \& Hachiya T., 1980: On the breeding activity of the Japanese field voles, Microtus montebelli, at Mizuhara in Fukushima City. Sci. Rep. Fukushima Univ., (30): 33-40. [In Japanese with English abstract].

21. Martell A. M., 1975: Taxonomic status of Microtus pennsylvanicus arcticus Cowan. J. Mammal., 56: 255-257.

22. Mayr E., 1963: Animal species and evolution. Belknap Press: 1-797, Cambridge.

23. McNab B. K., 1971: On the ecological significance of Bergmann's rule. Ecology, 52: $845-854$.

24. Miyao T., Morozumi M. \& Morozumi T., 1966: Small mammals of Mt. Yatsugatake in Honshu. VI. Seasonal variation in sex ratio, body weight and reproduction in the vole, Microtus montebelli. Zool. Mag., 75: 98-102. [In Japanese with English abstract]

25. Reichstein H., 1964: Untersuchungen zum Korperwachstum und zum Reproduktionspotential der Feldmaus, Microtus arvalis (Pallas, 1779). Z. wiss. Zool., 170: $112-222$.

26. Saito T., Machida K., Inoue S. \& Takahashi M., 1980: Reproductive activity of Microtus montebelli at Okegawa City in Saitama Prefecture. J. Mamm. Soc. Japan, 8: 122-128. [In Japanese with English abstract]

27. Shiraishi S., 1967: Some observations on the Japanese vole, Microtus montebelli, in the Chikugo river-bed, Kurume City. 1. Sex ratio, breeding season, and embryo size. J. Mamm. Soc. Japan, 3: 57-63. [In Japanese with English summary]

28. Snell R. S. \& Cunnison K. M., 1983: Relation of geographic variation in the skull of Microtus pennsylvanicus to climate. Can. J. Zool., 61: 1232-1241.

29. Snyder D. P., 1954: Skull variation in the meadow vole (Microtus p. pennsylvanicus) in Pennsylvania. Ann. Carnegie Mus., 33: 201-234.

30. Southern H. N. (ed.), 1964: The handbook of British mammals. Blackwell Sci. Publ.: 1-465, Oxford.

31. Stein G. H. W., 1957: Materialien zur Kenntnis der Feldmaus Microtus arvalis P. Z. Säugetierk., 22: 117-135. 
32. Tast J., 1966: The root vole, Microtus oeconomus (Pallas), as an inhabitant of seasonally flooded land. Ann. Zool. Fenn., 3: 127-171.

33. Zejda J., 1971: Differential growth of three cohorts of the bank vole, Clethrionomys glareolus Schreb. 1780. Zool. Listy, 20: 229-245.

34. Zimmermann K., 1942: Zur Kenntnis von Microtus oeconomus (Pallas). Arch f. Naturg., N. F., 11: 174-197.

Received 3 July 1987, Accepted 7 September 1987.

Yukibumi KANEKO

\section{ZALEZNOSC WYMIAROW CZASZKI OD SZEROKOSCI GEOGRAFICZNEJ \\ U MICROTUS MONTEBELLI Z JAPONII}

\section{Streszczenie}

Na materiale 623 dorosłych osobników Microtus montebelli (Milne-Edwards, 1872) zebranych w 15 miejscach Japonii (Honshu, Kyushu i na wyspie Sado) (Ryc. 1, Tabela 1) sprawdzono zależność 11 wymiarów czaszki od szerokości geograficznej. U osobników obu płci stwierdzono istotną ujemną korelację między szerokością geograficzną a dlugością kondylobazalną (CB), wymiarami mózgoczaszki, części twarzowej, oraz szerokością międzyoczodolową. Nie znaleziono takiej korelacji z długością szeregu zębowego i for. incisivum (Ryc. 2 i 3). Te dane, wraz z innymi danymi z literatury sugerują, że w rodzaju Microtus większość gatunków i podgatunków, które nie podlegają regule Bergmana, występuje głównie w poludniowych szerokościach geograficznych pólkuli północnej. Natomiast gatunki potwierdzające regułę zamieszkują głównie na północy. 